\title{
Hypereutectic Al-Si Alloy with Completely Nodular Eutectic Silicon: Microstructure and Process
}

\author{
Ruyao Wang, Weihua Lu \\ Institute of Materials Science and Engineering, Donghua University, Shanghai, China
}

Email address:

ryaowang@yahoo.com (Ruyao Wang)

\section{To cite this article:}

Ruyao Wang, Weihua Lu. Hypereutectic Al-Si Alloy with Completely Nodular Eutectic Silicon: Microstructure and Process. International Journal of Materials Science and Applications. Vol. 5, No. 6, 2016, pp. 277-283. doi: 10.11648/j.ijmsa.20160506.17

Received: September 27, 2016; Accepted: October 11, 2016; Published: November 9, 2016

\begin{abstract}
The achievement of hypereutectic Al-Si alloys with completely nodular eutectic Si has been studied. The procedure contained two steps: firstly, achieving hypereutectic direct electrolytic Al-Si alloys (HDEASA) with completely eutectic structure and secondly, spheroidizing eutectic Si upon soaking. HDEASAs with Si level in the range from $13.2 \mathrm{wt} \%$ to $17.6 \mathrm{wt} \%$ were made from direct electrolytic eutectic $\mathrm{Al}-\mathrm{Si}$ alloy ingot and $\mathrm{Al}-50 \mathrm{wt} \% \mathrm{Si}$ hardener. As cast microstructure of HDEASA was composed of primary-free quasi-eutectic cells. In comparison with commercial alloys, the lower heating temperature of $505^{\circ} \mathrm{C}-515^{\circ} \mathrm{C}$ for $4-8 \mathrm{hrs}$ was required to fully spheroidize Si crystal, either fine fibrous or even flaky in casting. Most of the spheres ranged in size from $1.0 \mu \mathrm{m}$ to $4.0 \mu \mathrm{m}$. Many measurements were focused on the variety of Si phase size in eutectic cells against the distance from the center of the cells. The origin of granulation of primary-free quasi-eutectic $\mathrm{Si}$ crystal is associated with its thermodynamic structural instability, accompanied by crystallographic defects, related to the electrolytic process.
\end{abstract}

Keywords: Hypereutectic Al-Si Alloy, Electrolysis, Primary-Free Quasi-Eutectic Cell, Spheroidization, Silicon Nodule

\section{Introduction}

Hypereutectic Al-Si alloy offering excellent wear resistance, lower density and thermal expansion coefficient, and superior dimensional stability at high temperature is selected as the material for the fabrication of automotive components and other wear-resisting parts as the drive to reduce fuel consumption and $\mathrm{CO}_{2}$ emissions has recently become more intense. Its large scale application began in the late 1970s [1]. However the appearance of coarse primary Si crystals seriously impairs its strength, toughness and machinability, limiting its usage in industry. Over several decades, many treatments have been focused on how to refine and modify the primary $\mathrm{Si}$ phase in hypereutectic alloys. They fall into three groups: chemical method, physical method and combined method. Chemical treatment is often used in practice, including the addition of an individual element or combination. In 1953 Mascre reported that the primary $\mathrm{Si}$ in hypereutectic alloys could be made dendritically or roughly spherical in chill casting by adding $\mathrm{Na}$ in the range of $0.05 \mathrm{wt} \%$ to $0.1 \mathrm{wt} \%$ to the melt [2]. In 1989 it was found that a combined $\mathrm{Na}-\mathrm{Sr}$ treatment can result in a great number of fine spherical Si crystals [3]. However, the increase in porosity with Na-addition severely deteriorated the properties of the alloy. Trace addition of any elements such as: P [4, 5], S [6], B [7], La [8], Ce [9], and $\mathrm{RE}$ [10-12] brings about refinement of primary $\mathrm{Si}$ in different degrees. Among these, P-addition significantly causes a reduction in the size of primary Si particles, increasing the number evenly distributed through the eutectic matrix. The combination of $\mathrm{Si}+\mathrm{P}$ [13], RE+P [14], B+P [15] or Al-Ti-C [16] strongly enhances the refinement effect on primary $\mathrm{Si}$ induced by P-addition with modified eutectic $\mathrm{Si}$. Recently it was found that adding a small amount of $\gamma-\mathrm{Al}_{2} \mathrm{O}_{3}$ nanoparticles simultaneously refined and modified the $\mathrm{Si}$ particles, and reduced the porosity in cast $\mathrm{Al}-20 \mathrm{Si}-4.5 \mathrm{Cu}$, resulting in unusual ductility enhancement $[17,18]$. But these chemical additions, either individually or complex, don't lead the morphological change from multi-faceted primary Si into spheres. The physical method involves overheating [19-21], electromagnetic stirring $[22,23]$ and electric current $[24,25]$ which greatly refine the primary $\mathrm{Si}$ and modify its 
morphology. However, expensive equipment and complex operation restrict their usage in foundry. Quenching treatment achieved by chill casting and rapid cooling with melt spinning [26] comprise the powerful physical tool to reduce the size of primary Si. Note that those treatments are inapplicable in sand castings or for large castings. In recent years the combined methods have been developed. F. Y. Cao reported that superheating hypereutectic Al-Si alloy modified with the addition of $\mathrm{P}$ can reduce the size of primary Si from $145 \mu \mathrm{m}$ to $38 \mu \mathrm{m}$, then after heat treatment at $535^{\circ} \mathrm{C}$ for $12 \mathrm{hr}$ the edges of primary Si become blunt, whereas the eutectic Si transforms to the spherical shape [27]. At the beginning of this century the author developed a combined process to nodulize the $\mathrm{Si}$ crystals, either eutectic or primary, in hypereutectic Al-Si alloy in two steps; firstly by adding the master alloy with several compositions (P, B, Ti and RE) to the melt, and then by heating the modified alloy at $510^{\circ} \mathrm{C}$ $520^{\circ} \mathrm{C}$ for $8 \mathrm{hr}$ to granulate the eutectic Si aggregate and make the primary $\mathrm{Si}$ crystal smooth and round [28, 29]. Achievement of a fully quasi-eutectic structure is another method to modify the primary Si phase. In the 1980s it was reported that the 3HA alloy, which contains up to $15 \mathrm{wt} \% \mathrm{Si}$ and $0.1 \mathrm{wt} \% \mathrm{Sr}$ exhibits a completely eutectic microstructure during directional solidification [30]. However, the microstructural benefit was offset by the appearance of porosity in the alloy. Recently M. Shamsuzzoha et al [31] reported that hypereutectic alloys having $14 \mathrm{wt} \%-17 \mathrm{wt} \% \mathrm{Si}$ prepared by the addition of $\mathrm{Ba}$ in the range of $1 \mathrm{wt} \%-4 \mathrm{wt} \%$ induced a very fine eutectic structure with a very small amount of refined primary Si. It is of interest, as reported in our previous study [32], that direct electrolytic Al-Si alloy (DEASA) ingots having up to $12 \mathrm{wt} \% \mathrm{Si}$ solidify in a selfmodified manner, accompanied by a large amount of Aldendrite. Moreover, electrolytic hypereutectic Al-Si alloys with Si concentration up to $17 \mathrm{wt} \%$ made from DEASA ingot provided a primary-free completely eutectic structure, even in a modified manner [33]. The most important event is that the eutectic $\mathrm{Si}$ precipitation in DEASA becomes small nodules after heating at a lower temperature of $505^{\circ} \mathrm{C}-515^{\circ} \mathrm{C}$ in a shorter time of 4-8 hrs [34] than in a Na-modified eutectic Al-Si alloy [35]. It would be expected that such a hypereutectic Al-Si alloy is capable of a spheroidizing $\mathrm{Si}$ phase at a lower temperature of near $510^{\circ} \mathrm{C}$ for a shorter heating time. If so, undoubtedly, it would represent a superior potential to challenge the increasing demand for lightweight alloy in automobile components in the near future and a new way of producing hypereutectic Al-Si alloy with completely smaller nodular $\mathrm{Si}$ offering high strength, toughness and wear-resistance. In this paper the aim focuses on the following:

- Observe the microstructural characteristics in as-cast hypereutectic electrolytic Al-Si alloys

- Observe the microstructural variety in hypereutectic $\mathrm{Al}-\mathrm{Si}$ alloys heated at a lower temperature of $505^{\circ} \mathrm{C}$ $515^{\circ} \mathrm{C}$.

- Study the effect of the Si level on the microstructural characteristics.

\section{Experimental Procedure}

Eutectic DEASA (EAl-12Si, Table 1) ingot of $10 \mathrm{Kg}$ and Al-50\% Si master alloy along with other master alloy additions were used to make Al-Si alloys in the range of $11 \mathrm{wt} \%$ to $18 \mathrm{wt} \% \mathrm{Si}$ in a $2 \mathrm{~kg}$ graphite crucible in an electric furnace which was heated to $850^{\circ} \mathrm{C}$. The hardeners added were stirred into the melt. No modifier was added to the melt. After melting, homogenization of the molten alloy was held for $15 \mathrm{~min}$., and then poured into a metallic mold, preheated to $250^{\circ} \mathrm{C}$ to form a casting of $40 \times 50 \times 120 \mathrm{~mm}^{3}$. Pouring temperature was about $740^{\circ} \mathrm{C}$ for all alloys tested. A chromel-alumel thermocouple of $0.1 \mathrm{~mm}$ diameter was put into the center of the casting and the temperature measurement was recorded by both a potentiometer and a digital potentiometer. The cooling rate during solidification was about $1.0^{\circ} \mathrm{C} / \mathrm{sec}$. DEASA ingot is made from Chinese bauxite [36]. The chemical analyses of the alloys tested are listed in Table 1. Note that the amount of modifying elements, e.g. Sr, Ca and others is less than the critical level required to modify the eutectic $\mathrm{Si}$ as reported in our previous studies [32, 33]. It is expected that the morphological characteristic in HDEASAs doesn't associate with the trace elements. Specimens for microstructural observation were cut from the center of castings and heated at $505-515^{\circ} \mathrm{C}$ for 4-8 hrs in an electric furnace. The samples were polished in the conventional metallographic way and a series of image analysis measurements related to the $\mathrm{Si}$ aggregate were conducted with a Quantiment Q920.

Table 1. Chemical Analysis of HDEASAs tested (wt\%).

\begin{tabular}{llllllllllll}
\hline Alloy & $\mathbf{S i}$ & $\mathbf{M g}$ & $\mathbf{C u}$ & $\mathbf{M n}$ & $\mathbf{N i}$ & $\mathbf{F e}$ & $\mathbf{T i}$ & $\mathbf{S r}$ & $\mathbf{C a}$ & $\mathbf{Z n}$ & Remark \\
\hline EAl-12Si* & 11.76 & 0.60 & 1.27 & 0.39 & 0.10 & 0.26 & 0.10 & $<0.002$ & 0.001 & 0.0070 & DEASA ingot \\
EAl-13Si & 13.20 & 0.42 & 0.84 & 0.27 & 0.05 & 0.27 & 0.03 & 0.0020 & 0.001 & $<0.015$ & D**+3wt\%AS50*** \\
EAl-14Si & 14.20 & 0.52 & 0.85 & 0.28 & $<0.05$ & 0.25 & 0.04 & $<0.0007$ & $<0.001$ & 0.0015 & D+5wt $\% A S 50$ \\
EAl-15Si & 15.60 & 0.57 & 1.05 & 0.35 & 0.05 & 0.33 & 0.05 & 0.0017 & 0.001 & 0.0020 & D+8wt $\%$ AS50 \\
EAl-18Si & 17.60 & 0.39 & 0.75 & 0.25 & $<0.05$ & 0.35 & 0.04 & $<0.0006$ & $<0.001$ & 0.0017 & D+12 wt $\% A S 50$ \\
\hline
\end{tabular}

*E: electrolytic.**D: DEASA ingot.***AS50: Al-50wt\% Si master alloy.

The parameters measured were: width $b$ and length 1 , number of Si particles and the spacing between neighboring
Si grains. The ratio of length to width, i.e. aspect ratio, of silicon grain is defined as its spheroidization rate. The 
contour of Si grain is, to a great degree, elliptical with long and short axes. Length and width are defined as the length of long and short axes, respectively. The volume of a $\mathrm{Si}$ grain is evaluated according to its length and width. To study the variety of Si sizes and morphologies in eutectic cells, a series of concentric circles were drawn in the photographs of several cells. The difference between radii of two neighboring circles was $10 \mu \mathrm{m}$, and the widths and lengths of the $\mathrm{Si}$ grains in the spaces between two circles were measured.

As is well known, the eutectic arrest temperature, $T_{E}$, in $\mathrm{Al}-\mathrm{Si}$ alloy is related to the alloying elements such as $\mathrm{Si}, \mathrm{Mg}$, $\mathrm{Cu}, \mathrm{Mn}, \mathrm{Ni}, \mathrm{Fe}$ and $\mathrm{Zn}[37,38]$. In general the following equation (1) is used to estimate the change of $\mathrm{T}_{\mathrm{E}}$ in commercial alloys, where the total of $\mathrm{Al} \%+\mathrm{Si} \%$ is high, near $99 \%[39,40] . \mathrm{T}_{\mathrm{E}}\left({ }^{\circ} \mathrm{C}\right)=577-(12.5 / \% \mathrm{Si})[4.43(\% \mathrm{Mg})$ $+1.43(\% \mathrm{Fe})+1.93(\% \mathrm{Cu})+1.7(\% \mathrm{Zn})+3.0(\% \mathrm{Mn})+4.0(\%$ $\mathrm{Ni}$ )] (1) In present work the estimated eutectic arrest temperatures, $\mathrm{T}_{\mathrm{E}}$, range from $569^{\circ} \mathrm{C}$ to $573^{\circ} \mathrm{C}$, depending upon the composition of alloys tested. Thus the undercooling, $\Delta T$, will be $\Delta T=T_{E}-T_{E}^{\prime}(2)$ Where $T_{E}^{\prime}$ is the measured eutectic temperature for a given alloy.

\section{Results and Analysis}

The procedure used to achieve a hypereutectic Al-Si alloy with completely nodular eutectic Si contains two steps. The first step is to obtain a quasi-eutectic structure in casting, and the second step is to granulate the eutectic Si grain by soaking at high temperature.

\subsection{Achievement of Quasi-Eutectic Structure}

Eutectic EAl-12Si alloy ingot of $10 \mathrm{~kg}$ with $100 \times 70 \times 600 \mathrm{~mm}^{3}$ is an undercooled metal with excellent microstructural inheritance, displaying a hypoeutectic structure with a very fine self-modified eutectic structure upon remelting as shown in Figure 1 [32]. That is related to a depressed eutectic arrest temperature of $557^{\circ} \mathrm{C}$ in freezing, corresponding to a high undercooling $\triangle \mathrm{T}$ of $12^{\circ} \mathrm{C}$ estimated by equation (2), shifting the eutectic silicon content toward a higher level of $16 \mathrm{wt} \%$ [41-45]. In terms of the concept of eutectic shift a quasi-eutectic structure with Si levels up to $16 \mathrm{wt} \%$ can be obtained.

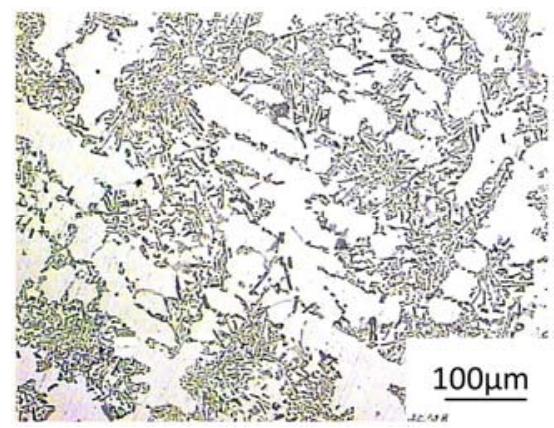

Fig. 1. As-cast micrograph of electrolytic eutectic EAl-12Si alloy. Optical.

For achieving hypereutectic alloys a larger amount of Al-
$50 \mathrm{wt} \% \mathrm{Si}$ master alloy is needed to add to the molten EAl12Si ingot (Table 1), substantially increasing the amount of unsolved Si particles acting as nuclei in the freezing of the alloys. Therefore a higher decrease in eutectic undercooling then appears, causing the considerable fading of selfstructural inheritance [33]. With increase in the Si content from $11.7 \mathrm{wt} \%$ (EAl-12Si alloy) to $13.2 \mathrm{wt} \%$ (EAl-13Si), to $14.2 \mathrm{wt} \%(\mathrm{EAl}-14 \mathrm{Si})$, and to $15.6 \mathrm{wt} \%(\mathrm{EAl}-15 \mathrm{Si})$ the eutectic undercooling gradually drops down from $12^{\circ} \mathrm{C}$ to $11^{\circ} \mathrm{C}$, to $9^{\circ} \mathrm{C}$, and to $7^{\circ} \mathrm{C}$, respectively, causing the alloys to grow into primary free quasi-eutectic structures in the different modified manner (Figure 2-4). As Si level increases, the average widths and lengths of the silicon crystals grow larger, producing higher aspect ratios (Fig. 5), implying that the microstructural fading gradually becomes stronger.

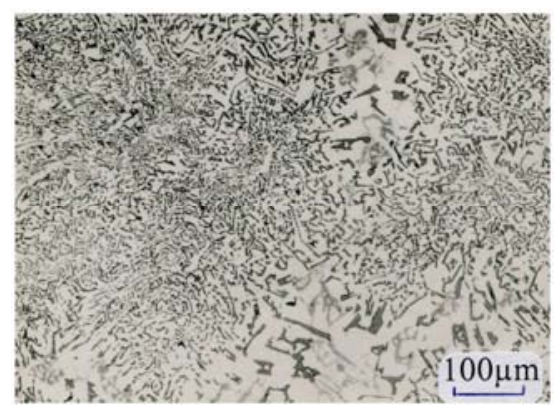

Fig. 2. As-cast microstructure of hypereutectic EAl-13Si alloy, which is composed of the quasi-eutectic structure. The eutectic cell is undistinguishable. Optical.

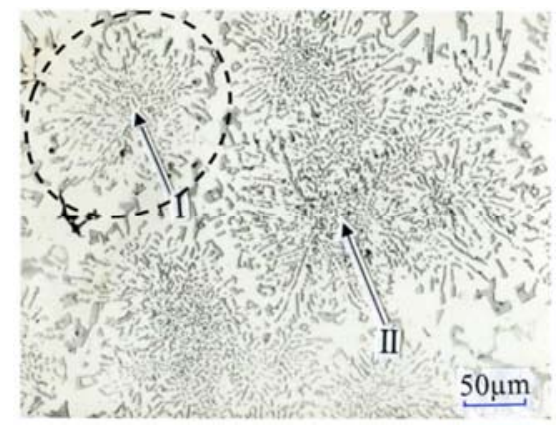

Fig. 3. As-cast micrograph of hypereutectic EAl-14Si alloy, showing the quasi-eutectic structure. Eutectic cell circled by dotted line grows as a nodule. I and II arrow indicate the cells, of which width and length are measured (Fig. 6) Optical.

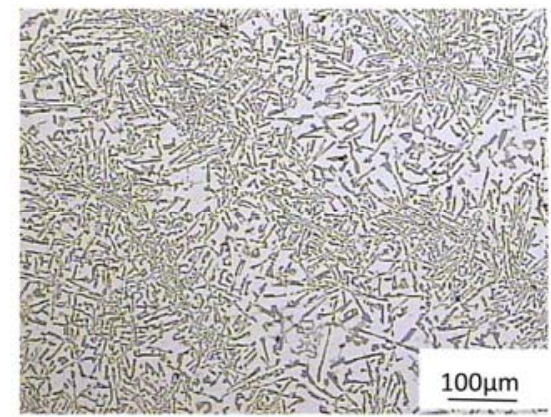

Fig. 4. As-cast microstructure of EAl-15Si alloy is composed of quasieutectic, which is subjected to considerable fading in self-modified structure. The cell boundary is unnoticeable. Optical. 
All the microstructures (Figure 2-4) are composed of many cellular eutectics. In the center of each cell the $\mathrm{Si}$ crystal exhibits a modified morphology, of which both width and length are very small with aspect ratios in the range of 2-3 (Figure 6). With an increase in distance from the center of the cell both dimensional parameters slowly increase. Meanwhile the aspect ratio remains almost unchanged. Finally, in the region near the boundary the Si grain becomes coarsened with the preferred growth direction, and a few faceted Si flakes even occur. In the EA1-18Si alloy with a low eutectic undercooling of $5^{\circ} \mathrm{C}$ the quasi-eutectic disappears, displaying the coarse angular primary Si crystals and the partially modified eutectic Si crystal. It is apparent that the eutectic undercooling of the alloy is an important factor in determining if the quasieutectic structure appears.
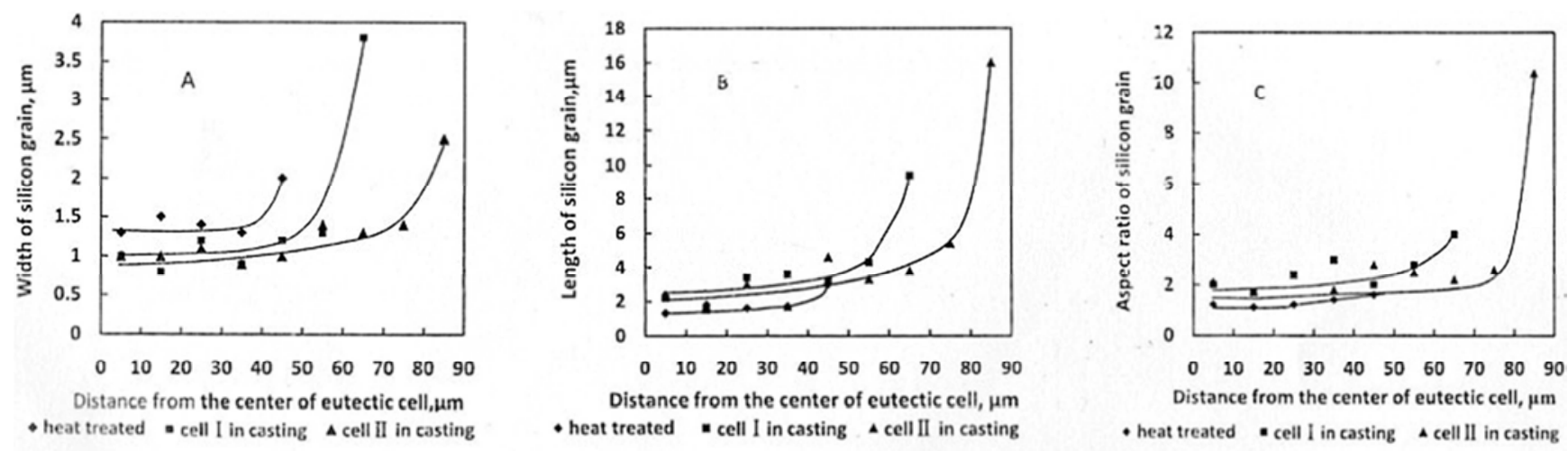

Fig. 6. Plot of distribution of width(A), length(B) and aspect ratio(C) of Si crystal in eutectic cell in as-cast EAl-14Si alloy (Figure 3) and after heat-treatment (Figure 10) against distance from center of eutectic cell.

Note that the EAl-15Si alloy is subjected to a considerable fading of the self-modified structure, the flaky Si crystal with an average length of about $11 \mu \mathrm{m}$ appears (Figures 4, 5). However, the microstructure is different from that of an unmodified alloy as shown in Fig. 7. As is well known, in untreated alloys the Si phase appears in the form of a large plate, which is composed of $\{111\}$ multiple twins with a $<112>$ preferred growth directions parallel to the $\{111\}$ plane $[46,47]$. The important microstructural feature is one in which that most sides and ends of the large plate are sharp and smooth, and on which there is no potential site to separate the plate into several smaller segments during heat treatment [35]. By contrast, in the HDEASA Si flake (Figure 7) is characterized by the fact that it contains only a single twin system, of which the twinning planes are not parallel to the growth direction, therefore the surface of the Si flake is very rough, with a lot of tips as in the Na-modified alloy [48]. Therefore, the quasi-eutectic microstructure would readily cause the variety of morphology upon heating, finally splitting the Si flake into several small pieces.

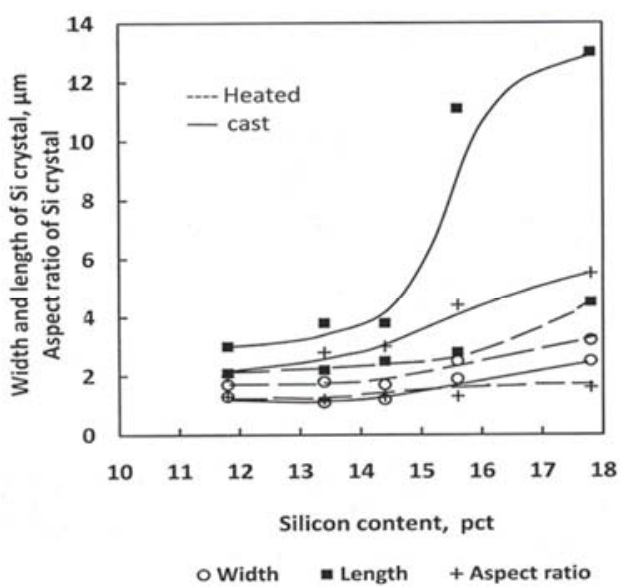

Fig. 5. Plot of width, length and aspect ratio of eutectic Si crystal in casting and upon heat-treatment vs. Si content in HDEASAs. 


\subsection{Spheroidization of Quasi-Eutectic Si Crystal}

After heating HDEASAs with $\mathrm{Si}$ level ranging from $11.7 \mathrm{wt} \%$ to $15.6 \mathrm{wt} \%$ at $505^{\circ} \mathrm{C}-515^{\circ} \mathrm{C}$ for $4-8 \mathrm{hrs}$ the quasieutectic Si crystals, either self-modified or flaky (Figures 14), are fully or almost subjected to spheroidization (Figures $8-11)$. Most of sphere size range from $1.0 \mu \mathrm{m}$ to $4.0 \mu \mathrm{m}$ independent of $\mathrm{Si}$ content. The outline of eutectic cell remains unchanged as in casting (Fig. 10), and Si nodules are well-distributed through Al-matrix. The Si sphere size slowly increases from the center to boundary of eutectic cell as indicated in Figure 6, while the aspect ratio nearly remains fixed ranging between 1.2 and 1.4. On the cell boundary Si coral grows suddenly larger, and a few of blunted polyhedra can be even observed as clearly seen in Fig. 10.

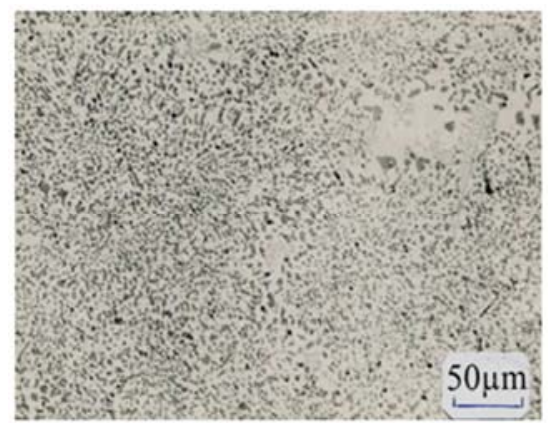

Fig. 9. Microstructure of EAl-13Sialloy (Fig. 2) upon heat-treatment. The boundary of eutectic cell is undistinguishable. Optical.

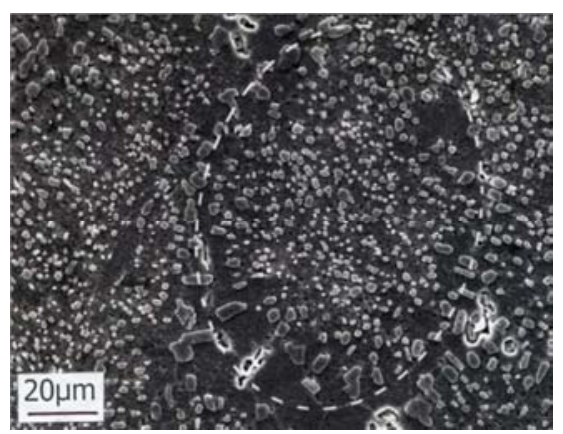

Fig. 10. SEM micrograph of EAl-14Si alloy (Fig. 3) upon heating. The outline of eutectic cell, which is indicated by dotted line and surrounded with the large Si grains either nodular or angular, remains unchanged as a nodule in casting. The diameter of cell is about 100 $\mu \mathrm{m}$. The most Si nodule size ranges from $1 \mu \mathrm{m}$ to $3 \mu \mathrm{m}$.

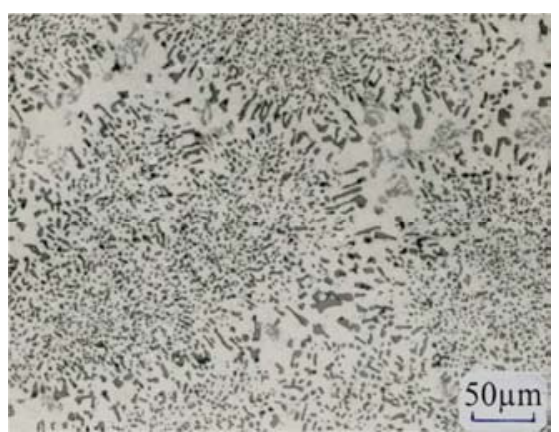

Fig. 11. Optical micrograph of EAl-15Si alloy (Fig. 4) upon soaking. The outline of as-cast eutectic cell is distinguishable.
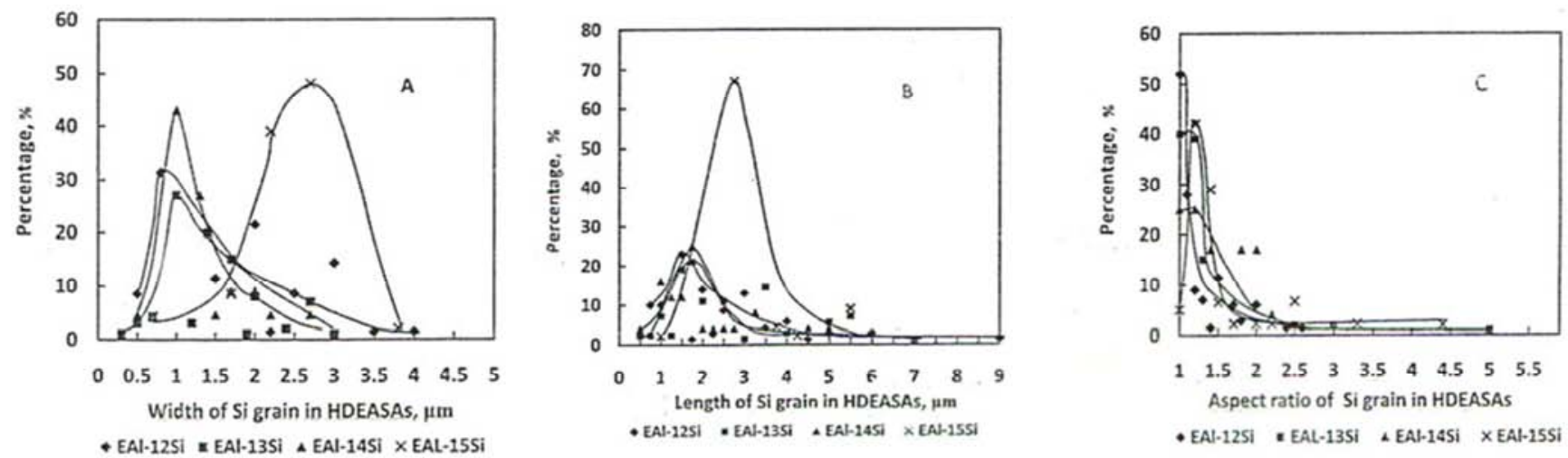

Fig. 12. Plot of distribution of width $(A)$, length $(B)$ and aspect ratio(C) of Si sphere in HDEASAs upon heat-treatment.

Experimental results demonstrated that the Si content is a major factor influencing the distribution of the widths, lengths and aspect ratio of Si nodule (Figure 12), and their average values (Figure 5). It is apparent that with increase in $\mathrm{Si}$ content from $11.5 \mathrm{wt} \%$ to $14.2 \mathrm{wt} \%$ the size of $\mathrm{Si}$ grain seems to be, if any, constant. As Si level is raised to 15.6 $\mathrm{wt} \%$, the size significantly becomes larger. And increasing Si concentration doesn't affect the aspect ratio, ranging from 1.2 to 1.5. In the EAl-18Si alloy the morphology of the angular primary Si crystal remains unchanged as in casting and the partially modified eutectic $\mathrm{Si}$ can be granulated in a great degree. Comparing the experimental results (Fig. 5, 6) it is reasonable to conclude that the refined $\mathrm{Si}$ crystal in casting is suitable to split into small Si coal. In addition with increase in Si level from $7 \mathrm{wt} \%$ to $11.5 \mathrm{wt} \%$ in hypoeutectic alloys the Si nodule number slowly decreases; meanwhile the particle volume and spacing between two neighboring $\mathrm{Si}$ grains insignificantly become larger (Figure 13). On the contrary, as $\mathrm{Si}$ content is raised from $11.5 \mathrm{wt} \%$ to $15.6 \mathrm{wt} \%$ in hypereutectic alloy the $\mathrm{Si}$ grain number suddenly drops down; its volume and spacing greatly increase. 


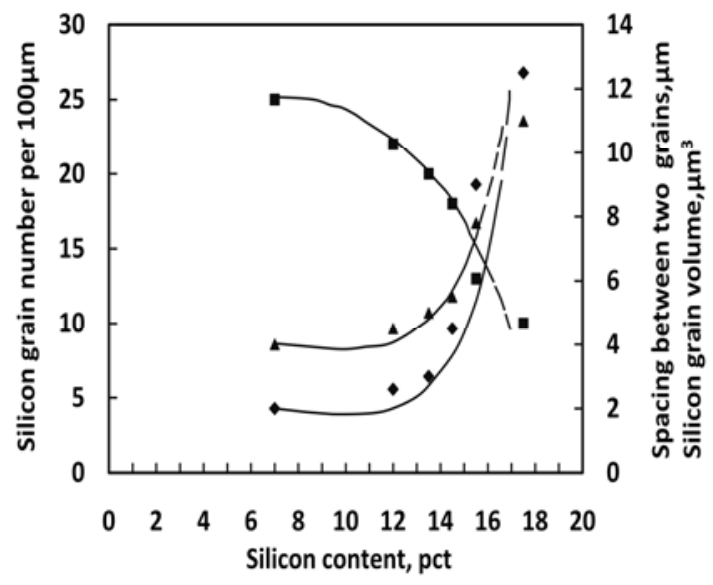

- silicon grain number per $100 \mu \mathrm{m}$ • silicon grain volume

$\Delta$ spacing between two grains

Fig. 13. Plot of volume, number and spacing of Si nodule against Si content in HDEASAs.

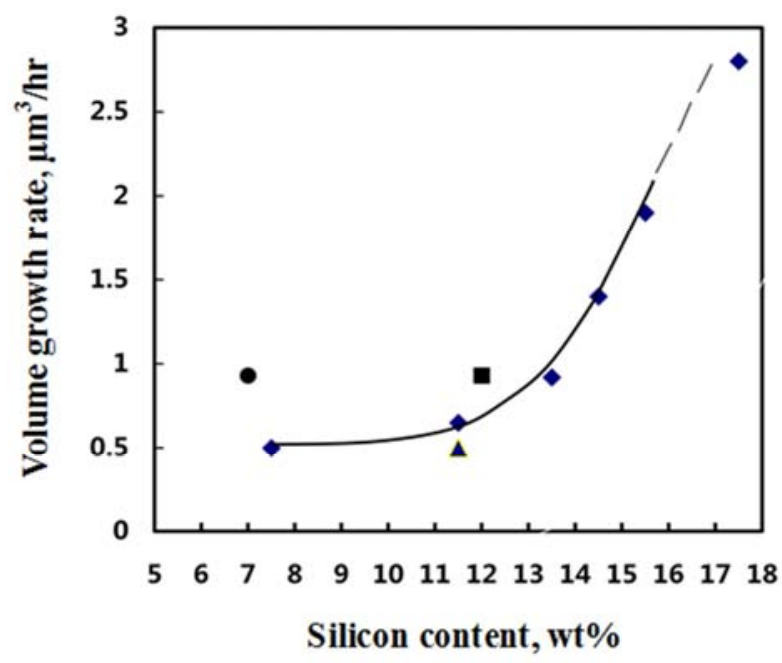

- volume growth rate in current study

na-mod.Al-12Si alloy, $545^{\circ} \mathrm{C}[35,49]$

$\triangle \mathrm{E} 108,510^{\circ} \mathrm{C}$, 8hrs [34]

- $\mathrm{A} 356,500^{\circ} \mathrm{C}$, thixoformed[50]

Fig. 14. Change in volume growth rate of Si nodule with Si content.

It is obvious that $\mathrm{Si}$ content greatly affects the spheroidization of $\mathrm{Si}$ crystal, in which $\mathrm{Si}$ diffusion is a controlling factor rather than kinetics of Si growth [34, 35]. Zhu and Lui indicated that the rate of diffusion of Si atoms from high to area of low energy is proportional to $\mathrm{Si}$ concentration, curvature of surface of $\mathrm{Si}$ grains and lattice deformation energy of Si phase, and inversely to the spacing of Si grains [35, 49]. In the undercooled HDEASAs there are three major factors accelerating the rate of mass transport of $\mathrm{Si}$ atoms in Al-matrix. The first is extension of Si solubility in Al-matrix beyond the equilibrium [45]. During heating Si atoms are readily rejected from the matrix, accelerating the diffusion rate of $\mathrm{Si}$ atom in Al-matrix. Secondly, one undercooling phase i.e. quasi-eutectic is formed rather than two equilibrium phases i.e. primary $\mathrm{Si}$ crystal and $\mathrm{Al}-\mathrm{Si}$ eutectic. The most important issue is that the higher the Si content, the coarser the primary Si grain. Thus, the primaryfree quasi-eutectic Si phase exhibits the higher lattice defect energy, strengthening the rate of diffusion of Si atoms in Almatrix. Thirdly, a lot of microstructural defects (Figure 7) displaying high curvature of surface of Si grain, increase Si diffusion rate in Al-matrix. As a result the rate of volume growth in HDEASAs is much higher than that in alloys, either hypoeutectic or eutectic. Moreover, as Si concentration is raised in HDEASAs the rate of volume growth significantly becomes larger as shown in Figure 14. That is reason why the volume of $\mathrm{Si}$ grain grows rapidly, accompanying with sharp decrease in number of Si grains as Si content is higher than $11.5 \mathrm{wt} \%$ (Fig. 13) although the spacing of $\mathrm{Si}$ grains becomes larger, reducing the rate of volume growth [35, 49]. It is an advanced superiority of HDEASA in production of hypereutectic Al-Si alloy with nodular Si. In other hand it might be a drawback for the components applied at high temperature.

\section{Conclusions}

(1) Hypereutectic Al-Si alloy containing $\mathrm{Si}$ content ranging from $13 \mathrm{wt} \%$ to $16 \mathrm{wt} \%$ with completely nodular Si can be achieved after heating alloy made from direct electrolytic eutectic Al-Si alloy at 505$515^{\circ} \mathrm{C}$ for $4-8 \mathrm{hrs}$.

(2) Achievement of the quasi-eutectic structure is most important for producing hypereutectic Al-Si alloy with completely nodular $\mathrm{Si}$.

(3) The higher the Si content, the stronger the tendency to grow into large nodules.

(4) A high eutectic undercooling in freezing of alloy is a key factor in obtaining small Si spheres.

(5) Spheroidization of $\mathrm{Si}$ phase at lower temperatures is attributed to thermodynamic structural instability and micro-structural defect of the $\mathrm{Si}$ crystal, which is related to the electrolytic process in the reduction pot.

\section{References}

[1] J. L. Jorstad, AFS Trans. 117, 241 (2009).

[2] C. Mascre, Foundry Trade J. 94, 725 (1953).

[3] N. Tenekedjiev and J. E. Gruzleski. AFS Trans. 97, 127 (1989).

[4] M. Adachi, J. Jpn. Inst. Light Met. 34, 430 (1984).

[5] H. S. Dai and X. F. Liu, Mater. Sci. Technol. 25, 1183 (2009).

[6] M. Tagami and Y. Serita, J. Jpn. Inst. Light Met. 22, 564 (1972).

[7] J. H. Pan, Q. L. Cui and M. X. Wang, Special Casting \& Nonferrous Alloy. 30, 85 (2010) (In Chinese). 
[8] H. K. Yi and D. Zhang, Trans. Nonferrous Met.Soc. China 13, 358 (2003).

[9] H. H. Zhang, H. L. Duan, G. J. Shao, L. P. Xu, J. L. Yin and B. Yan, Rare Met. 25, 11 (2006).

[10] T. Kowata, H. Horie, S. Hiratsuka and A. Chida, Imono. 66, 803 (1994) (In Japanese).

[11] J. Y. Chang, I. G. Moon and C. S. Choi, J. Mater. Sci. 33, 5015 (1998).

[12] Z. H. Qiu, Y. L. Li, H. Chen, J. C. Chen, G. D. Zhang and C. X. Pan, Special Casting\&Nonferrous Alloys. 35, 632 (2015) (In Chinese).

[13] Y. P. Wu, S. J. Wang, H. Li and X. F. Liu, J. Alloys Comp. 477, 139 (2009).

[14] N. C. Liu, J. Q. Li and Z. X. Liu, Adv. Mate. Research. 160, 189 (2010).

[15] X. Liu, Y. Wu and X. Bian, J. Alloys Comp. 391, 90 (2005).

[16] W. W. Ding, T. D. Xia, W. J. Zhao and Y. T. Xu, Materials. 7, 1188 (2014).

[17] H. S. Choi, H. M. Konishi and X. C. Li, Mater. Sci. Eng. A 541, 159 (2012).

[18] H. S. Choi and X. C. Li, J. Mater. Sci. 47, 3096 (2012).

[19] S. Popel, O. A. Tchikova, I. G. Brodova and V. V. Makeev, Nonferrous Met. no. 9, 53 (1992) (In Russian).

[20] C. Xu and Q. C. Jiang, Mater.Sci.Engr. A437, 451 (2006).

[21] J. Piatkowski and P. Kaminski, Archives of Foundry Engr. 15, 79 (2015).

[22] D. Lu, Y. Jiang, G. Guan, R. Zhou, Z. Li and R. Zhou, J. Mater. Proc. Technol. 189, no. 1-3, 13- (2007).

[23] F. C. RoblosHermandez and J. H. Sokolowski, J. Alloys Comp. 426, 205 (2006).

[24] C. Y. Ban, Y. Han, Q. X. Ba and J. Z. Cui, Mater.Sci.Forum 546-549, 723 (2007).

[25] L. J. He, J. Z. Wang, S. G. Qi, H. L. Du and Z. F. Zhao, Foundry China. 7, 153 (2010).

[26] N. Apaydin and R. W. Smith, Mater.Sci. Engr. A, 98, 149 (1988).

[27] F. Y. Cao, Y. D. Jia, K. G Prashanth, P. Ma, J. S. Liu, S. Scudino, F. Huang, J. Eckert and J. F. Sun. Mater. Design. 74, 150 (2015).

[28] H. Y. Yeh, H. G. Yeh, R. Y. Wang and W. H. Lu, U.S. Patent 6, 261, 390 B1. July 17, 2001.

[29] R. Y. Wang and W. H. Lu,. JOM64, 330 (2012).
[30] D. M. Smith, U.S. Patent 4, 434, 014, Feb. 28, 1984.

[31] M. Shamsuzzoha and F. Jueretzka, Dual Refinement of Primary and Eutectic Silicon in Hypereutectic Al-Si Alloys. Aluminum Alloys for Transportation, Packaging, Aerospace and other Applications. Proceedings of A Symposia Sponsored by the Light Metals Division of TMS and Ed. S. K. Das and W. M. Yin. pp. 153-162, TMS 2007 Annual Meeting and Exhibition.

[32] R. Y. Wang, W. H. Lu and L. M. Hogan, Mater. Sci. Engr. A 348, 289 (2003).

[33] R. Y. Wang, W. H. Lu and Z. Y. Ma, AFS Trans. 115, 241 (2007).

[34] R. Y. Wang and W. H. Lu, Metall. Mater. Trans. A. 44, 2789 (2013).

[35] P. Y. Zhu and Q. Y. Liu, Mater. Sci. Technol. 2, 500 (1986).

[36] G. Q. Yang, Chinese Patent, ZL94 116 235.4, Sept. 28, 1994 (In Chinese).

[37] G. Stuhldreier and K. W. Stoffregen, Giesserei. 68, 404 (1981).

[38] K. W. Stoffregen, Giesserei, 72, 545 (1985).

[39] L. F. Mondolfo, Aluminum Alloys, Structures and Properties. Butterworths and Co., London. 1979, pp. 513-15, 534-37, 566-75, 592-94, 604 and 617-18.

[40] D. Apelian, G. K. Sigworth and K. R. Whaler. AFS Trans. 92, 297 (1984).

[41] S. P. Li, X. C. Chen, O. M. Barabasch and S. P. Oschkoderov, Acta Metall.Sin. 31, A47 (1995) (In Chinese).

[42] O. A. Atasoy, F. Yilmaz and R. Elliott, J. Crystal Growth, 66, 137 (1984)

[43] D. C. Jenkinson and L. M. Hogan, J. Crystal Growth 28, 171 (1975).

[44] H. A. H. Steen and A. Hellawell, Acta Metall. 20, 363 (1972).

[45] El-BenawyTalaat and H. Fredriksson, J. Jap. Inst. Light Met. 41, 507 (2000).

[46] M. Shamsuzzoha, L. M Hogan and L. M. Berry.. AFS Trans. 100, 619 (1992).

[47] S. Z. Lu and A. Hellawell, J. Crystal Growth, 73, 316 (1985).

[48] S. Z. Lu and A. Hellawell,. Metall. Trans. A. 18, 1721 (1987).

[49] P. Y. Zhu, Q. Y. Liu and T. X. Hou,. AFS Trans. 93, 609 (1985).

[50] E. Ogris, H. Lüchinger and P. J. Uggowitzer. Mater.Sci.Forum 396-402, 149 (2002). 